Chirurgia (2018) 113: 70-82

No. 1, January - February

Copyright@ Celsius

http://dx.doi.org/10.21614/chirurgia.113.1.70

\title{
New Minimally Invasive Endoscopic and Surgical Therapies for Gastroesophageal Reflux Disease (GERD)
}

\author{
Alexandru Eugen Nicolau' ${ }^{1}$, Adrian Lobonțiu², Silviu Constantinoiu ${ }^{3}$ \\ 1Department of Surgery, Emergency Clinical Hospital Bucharest, Romania \\ 'EndoGastric Solution, Redmond, WA, USA \\ ${ }^{3}$ Department of General and Esophageal Surgery, Center of Excellence in Esophageal Surgery, Sf. Maria Clinical Hospital, Bucharest, Romania
}

Corresponding author:

Alexandru Eugen Nicolau, MD

Department of Surgery

Emergency Clinical Hospital

Bucharest, Romania

E-mail: aenicolau@gmai.com

\section{Rezumat \\ Noi terapii miniminvazive endoscopice și laparoscopice în boala de reflux gastroesofagian (BRGE)}

BRGE a devenit cea mai frecventã afecțiune a polului digestiv superior, afectiune spectralã şi evolutivã cu posibile complicații severe. Terapia principalã şi efectivã în majoritatea cazurilor este tratamentul medical (TM) axat pe IPP. Cazurile severe cu alterarea funcției sfincterului esofagian inferior (SEI) şi modificãri anatomice importante vor fi abordate chirurgical, fundoplicatura laparoscopicã (FL), intervenția de elecție, cu rezultate bune la distanțã, dar cu posibile efecte negative postoperatorii. 30-40\% dintre pacienți sunt refractãri la TM, dar mulți nu doresc intervenția chirurgicalã. Apare un "gol terapeutic", pacienți cu BRGE care nu beneficiazã de tratament. Pentru pacienții cu BRGE, selectați, fãrã forme severe şi complicații şi fãrã modificãri anatomice importante (hernii hiatale mici), în mod special pentru cei refractari la TM, au apãrut noi terapii miniminvazive: mai eficiente ca şi TM, dar mai puțin agresive şi cu efecte secundare minime comparativ cu FL. Sunt terapii endoscopice care amelioreazã funcția SEI prin terapie termicã, procedeul Stretta ${ }^{\circledR}$ şi rezecția mucoasei antireflux, respectiv realizarea unei fundoplicaturi parțiale cu ajutorul unor dipozitive de agrafare: EsophyX ${ }^{\circledR}$, Muse $^{\mathrm{TM}}$, Gerd-X ${ }^{\mathrm{TM}}$. Tehnicile laparoscopice pot rezolva HH mai mari (peste $2 \mathrm{~cm}$ ) când se impune, iar în locul fundoplicaturii se poate monta un şirag de mãrgele magnetice la nivelul joncțiunii gastroesofagiene, procedeul LINX®, respectiv electrozi pentru stimulare electricã a SEI, EndoStim ${ }^{\circledR}$. Aceste procedee s-au dovedit 
sigure şi eficiente pe termen scurt şi pe un numãr relativ redus de cazuri. Rezultatele promițãtoare obținute, obligã la perfecționarea dispozitivelor, studii randomizante complexe, comparative, evaluare la distanțã, pentru o selecție cât mai adecvatã a pacienților şi a terapiilor.

Cuvinte cheie: boala de reflux gastroesofagian (BRGE), laparoscopic fundoplicatura, Stretta, EsophxyX, Muse, GERDX, LINX, EndoStim

\begin{abstract}
GERD has become one of the most frequent pathology of the upper GI tract. It is a spectrum disease and is a progressive disease as well. Serious and severe complications are possible. The mainstream therapy in most of the patients is the medical therapy with PPI's. The most severe cases with an impaired LES (Lower Esophageal Sphincter) function as well as important anatomical disruptions are of surgical indication, the gold standard being laparoscopic fundoplication, an elective therapy with long term follow up outcomes at the expense of de novo symptoms associated with fundoplications in general. $30 \%$ to $40 \%$ of the patients are PPI refractory with partial symptom control, but they are not willing to go for the laparoscopic fundoplication because of the invasive character and because of potential postfundoplications syndromes. There is a "treatment gap" for these patients with GERD. For a well selected patient population with GERD, with mild forms of the disease, without complications and without major anatomical disruptions (patients with small hiatal hernias), patients who are refractory on PPI medication, there are today new alternative therapies, minimally invasive. These therapies are less aggressive and basically with no side effects or new onset symptoms that Laparoscopic Fundoplications will give. These are endoscopic therapies which improve the LES function: Stretta utilizes radiofrequence therapy, a novel technique describes mucosal resection at the level of the cardia, while a partial fundoplication from within the stomach can be realized with EsophyX, Muse or Gerd-X. Form all these procedures, EsophyX is the most advanced with more than 20,000 patients treated worldwide, with good clinical outcomes and with no de novo symptoms. The laparoscopic techniques treat hiatal hernias larger than $2 \mathrm{~cm}$. Linx utilizes a magnetic ring at the LES level. EndoStim utilizes electrodes in order to stimulate the LES muscle. These procedures are effective on short term and there are few patients treated with Linx or EndoStim. More research for Linx and EndoStim is necessary with randomized clinical trials, with improvement of the devices and with long term follow up.
\end{abstract}

Key words: Gastro Esophageal Reflux Disease (GERD), Laparoscopic Fundoplication, EsophyX, Stretta, Muse, Gerd-X, Linx, EndoStim

\section{Introduction}

GERD has become one of the most common chronic diseases of the upper digestive tract and is continuously expanding. The incidence of the disease, based on typical symptoms, is credited to $18-27.8 \%$ of the adult population in the US, $8.8-26 \%$ in Europe and only $2.5-7.8 \%$ in Asia (1). According to the Consensus
Conference in Montreal, GERD is defined as a pathological condition that occurs when gastric reflux causes bothersome symptoms and/or complications (2). Esophageal lesions, erosive GERD, represented by erosive esophagitis (EE) and local complications, stenosis, Barett's esophagus (BE), esophageal adenocarcinoma (ACE) and/or distant lesions, reflux pulmonary fibrosis, pseudoangina syndrome, reflux 
laryngo-pharyngitis, sinusitis, or dental reflux erosions can also occur (2).

GERD development is multifactorial, the causes being still incompletely elucidated, but there is certainly an association, alteration of esophageal peristalsis, alteration of the lower esophageal sphincter (LES) function, of gastric emptying, to which duodenal gastric reflux can be added. Axial or mixed hiatal hernia $(\mathrm{HH})$ plays a determining role in the onset and worsening of GERD, alters the LES function with increased transient relaxation, ineffective contraction, esophageal hiatus enlargement, Hiss angle alteration, alteration of esophageal peristalsis, "acid reservoir" effect (3). If the disease is not properly treated, it may evolve to fibrosis of mucosal muscles due to repeated episodes of esophagitis, or to $\mathrm{BE}$ and esophageal adenocarcinoma (EAC) (4). BE incidence sees an alarming increase parallel to GERD and, unfortunately, to EAC, 6-14\% of patients with GERD progressing towards development of BE, a precancerous state, and of these $0.5-1 \%$ will ultimately develop EAC. Patients with BE have, over the course of their lifetime, a risk 50-100 times greater of developing EAC, a highly aggressive form with low survival rate $(5,6)$. The correct and complete diagnosis of GERD followed by appropriate treatment of the case is crucial, both for improving the quality of patients' lives and for preventing the occurrence of severe forms and complications. The standard approach of GERD is medical treatment (MT), based on antacid therapy, $\mathrm{H} 2$ receptor inhibitors, and especially proton pump inhibitors (PPIs), which are the most used and most effective, to which prokinetics can be added, as well as changes in lifestyle and diet, respectively. PPIs are the most effective, as they block the acid pump (7). PPI therapy is effective, especially in those with EE, well tolerated, but also presents some hard to dismiss inconveniences $(8,9,10)$ :

- reduced effect in those with regurgitation;

- after discontinuation of treatment, the majority of patients experience symptoms;
- $20-40 \%$ of patients are refractory to treatment with PPIs, meaning that either therapy has no effect, and they are non-responders, or the effect is partial;

- an absence of or partial effect in those with atypical symptoms;

- side effects in those with "á la long" treatment, but with a reduced incidence, osteoporosis, mineral and vitamin deficiency, risk of clostridium difficile infection, renal impairment, etc.;

- does not significantly influence the evolution of BE to EAC.

Those who do not respond to PPI therapy, as well as those with non-erosive GERD, require impedance $\mathrm{pH}$-metrics and manometry, the cause of therapy inefficiency being neutral or alkaline reflux, which is more dangerous, as it favours the appearance of BE (9). In fact, drug therapy is most effective in those with EE, but does not influence the anatomical changes present in case of $\mathrm{HH}$ coexistence, which aggravate the condition. Recently, those refractory to PPIs respond to vanoprazan, a "potassium-competitive acid blocker" that has a much stronger inhibitory effect on acid secretion from gastric parietal cells. Baclofen is also efficient in reducing transient relaxation of the LES, a "GABA-B agonist", which unfortunately also has side effects, reason for which it is not approved by the FDA $(11,12)$.

Surgical anti-reflux treatment has seen a revival with the first floppy-Nissen laparoscopic fundoplication (LF) by Bernard Dallemagne in 1991. This opened the path to minimally invasive therapy, with all its well-known advantages, Nissen LF (NLF) becoming the "gold standard" in surgical therapy (13). Fundoplication associated with esophageal hiatus calibration is the only one that can restore the anti-reflux barrier in patients with GERD, with the disappearance of typical and atypical symptoms in most patients and improvement of quality of life: restores LES function, prevents acid and non-acid reflux, reduces $\mathrm{BE}$ and $\mathrm{EAC}$ risk, restores the anatomy of the gastroesophageal junction in those with $\mathrm{HH}$. Good results at a distance are present in over $90 \%$ of cases (12). Of course, there are 
some inconveniences $(14,15)$ :

- reconstructive surgery, dependent on the surgeon's experience;

- there are technical variants of total or partial fundoplication, each with its pro's and con's, currently the most frequently used being NLF, Toupet respectively.

- early side effects, dysphagia, gas-bloating, impossibility of vomiting, especially in the case of NLF, which is however more effective over time;

- a recurrence of symptomatology that may require resumption of PPI therapy, or even reintervention in $0-6 \%$ of cases.

By comparing medical treatment with NLF in a meta-analysis of 11 publications with 7 randomized control trials (RCT) and 1,972 patients followed-up for periods between 1-12 years, the quality of life was superior in the group of patients submitted to surgery (16). The results of NLF 20 years after the intervention and of open approach Nissen fundoplication 30 years after surgery, are good: $90 \%$ of patients satisfied in the first group (94\% asymptomatic), $81.4 \%$ did not present dysphagia, and only $5.8 \%$ were under treatment with PPIs for pyrosis in the second group $(17,18)$. At 5 years, the quality of life of patients submitted to NLF was superior and the costs of treatment were lower compared to patients treated with PPIs over the same time period (19).

In the US, less than $1 \%$ of patients with GERD end up requiring surgery, indicating that LF is "underutilized", and patients receive in most cases medical therapy in a gastroenterology service (20). Surgical treatment is recommended especially for patients with no response to MT, those with atypical symptoms, with large $\mathrm{HH}$, with $\mathrm{EE}$, with complications (stenosis, BE), those with defective LES $(4,14,15)$. Considering that $30-40 \%$ of patients respond partially to MT or do not respond at all, but are also reluctant to surgery out of fear of postoperative side effects, there is a "therapeutic gap" - patients with GERD who do not benefit from an effective treatment $(9,21)$. For over 15 years, minimally invasive therapies have been developed specifically for these patients. These minimally invasive procedures aim at improving the LES function and creating an anti-reflux barrier, representing a type of "bridge therapy" between MT and LF. These therapies must be more effective than MT, easier to perform, less invasive, with fewer side effects compared to LF. At the same time, in the case of recurrence of GERD, LF can be performed. These techniques selectively address patients who do not present important anatomical changes $(\mathrm{HH}>2-3 \mathrm{~cm})$, do not have severe reflux (esophagitis Los Angeles grade C, D, esophageal stenosis, BE) $(21,22,23)$.

These new therapies are endoluminal, endoscopic and new laparoscopic therapies. To evaluate as objectively as possible the efficacy of these new procedures, one-year studies should mandatorily be RCTs and $3-5$ years should be allotted to other types of studies (uncontrolled study design). Thus, control of PPI treatment is considered to be effective when $50 \%$ of patients discontinue therapy after 1 year in a RCT or after 3-5 years in uncontrolled studies, but also present normalization of esophageal acid exposure (total \% time $\mathrm{pH}$ $<4$ ), or at least a $50 \%$ reduction. Improving the Quality of Life GERD-HRQL (The Gastroesophageal Reflux Disease-Health Related Quality of Life) is mandatory $(23,24)$.

Current endoscopic therapies are represented by 5 procedures: radiofrequency, endoscopic fundoplication, 3 techniques, and anti-reflux esophageal mucosa resection. These address patients without $\mathrm{HH}$ or with $\mathrm{HH} \leq 2 \mathrm{~cm}$. Laparoscopic therapies are represented by magnetic augmentation of the LES, and electric stimulation of LES, respectively, and can also be applied to patients with $\mathrm{HH}$ over 2-3 cm (25).

\section{Endoscopic Therapies}

Endoscopic therapies are represented by radiofrequency heat treatment, Stretta procedures (Mederi Therapeutics, Greenwich, CT, USA), anti-reflux resection of the gastroesophageal junction (GEJ) mucosa by electrocoagulation (ARMS: anti-reflux mucosectomy), and endoscopic staplers respectively, by performing an endoscopic partial fundoplication, transoral fundoplication with EsophyX ${ }^{\circledR}$ (TIF: 
Transoral Incisionless Fundoplication) [Endo Gastric Solutions, Redmond, WA, USA], MUSE $^{\mathrm{TM}}$ ultrasound endoscopic endostapler (Medigus, Omer, Israel), GERDX TM fullthickness plication endoplication (G-SURG GmbH, Seeon-Seebruck, Germany).

Stretta is a procedure by which a $20 \mathrm{Fr}$ bougie tip with a balloon that opens in a surrounding basket, when endoscopically directed at the level of the LES, delivers radiofrequency current through 4 electrodes inserted into the junctional muscle tissue, and determines LES fibrosis with LES tonicity improvement and better anti-reflux barrier (Fig. 1, 2). This procedure is the oldest endoscopic technique approved by the Federal and Drug Administration (FDA) in the year 2000 and recommended by SAGES (Society of American Gastrointestinal and Endoscopic Surgeons) in 2013 (quality of evidence: ++++; grade recommendation: strong) and again in $2017(26,27)$. In a first meta-analysis of 18 published articles (2RCT), comprising 1,441 patients who were submitted to the Stretta procedure (2001-2010), symptoms postoperatively, as well as GERD-HQRS, AEE was reduced, without normalization, LES pressure improved with no statistical significance (28). The efficiency of the Stretta procedure was evaluated at 10 years in a group of 99 patients, which were nonresponsive to PPIs: GERDHQRS normalized in $72 \%$ of patients, $41 \%$ discontinued PPI treatment, 54\% were satisfied, 11 required reintervention by Stretta procedure, $85 \%(5 / 33)$ of patients with $\mathrm{BE}$ and biopsy regressed. There were no side effects, proving a viable treatment for GERD (29). In 2015, a meta-analysis of 4 RCTs (3 Stretta versus Sham, one Stretta versus PPI) was published, with 159 evaluated patients, concluding that the procedure did not determine significant changes in patients with GERD (30). However, the latest published meta-analysis, including 28 studies (4 RCTs) with 2,468 patients followed for an average period of 25.4 months, shows a statistically significant postoperative improvement in GERD-HRQL (-14.1, p <0.001), in heartburn standardized score by $-1.53[-1.97,-1.09](\mathrm{P}<$ $0.001)$, and in AEE (-3.01; p<0.001). 51\% of patients were no longer using PPIs, and LES pressure was slightly increased, with no statistical significance. In conclusion, Stretta is a therapeutic alternative in patients with GERD who do not accept LF (31). After Stretta treatment, only $49 \%$ of the patients using proton pump inhibitors (PPIs) at baseline required PPIs at follow-up $(\mathrm{p}<0.001)$. Stretta treatment reduced the incidence of erosive esophagitis by $24 \%(\mathrm{p}<0.001)$ and reduced esophageal acid exposure by a mean of -3.01 $[-3.72,-2.30](\mathrm{P}<0.001)$. The Stretta procedure proved safe and effective in improving the quality of life, the satisfaction index, and reducing drug treatment in 18 patients with refractory GERD after NLF. Stretta has the advantage of a simpler technique with less severe complications compared to NLF, and can be the first option in these patients (32). In selected patients, Stretta, a mature technology,

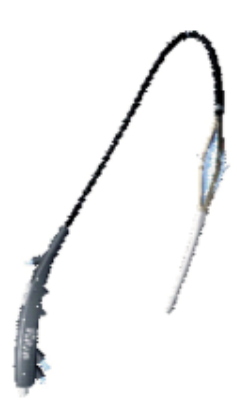

Figure 1. Stretta device

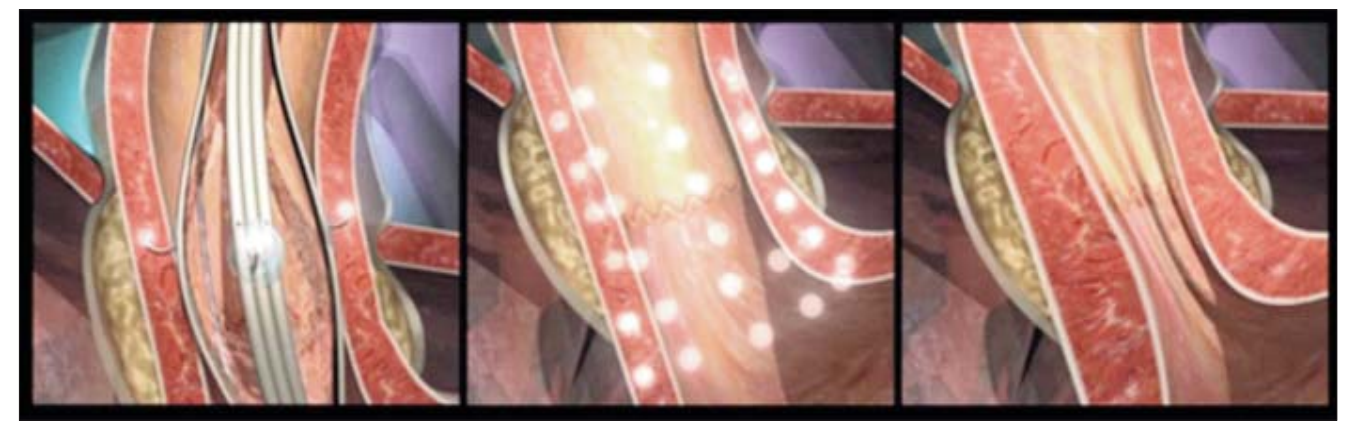

Figure 2. Stretta procedure 
is more effective than PPIs, but less so than $\mathrm{LF}$, and is safe, repeatable, and has a short learning curve (33).

TIF is the most well-known and most frequently used endoluminal procedure for obtaining a partial gastroesophageal valve and restoration of the Hiss angle, according to the anatomical principle of the Nissen fundoplication (4). TIF is performed with the EsophyX device, a single use over the endoscope surgical instrument, creating a partial minimum 270 degrees' fundoplication, $2-3 \mathrm{~cm}$ in length. This is obtained through the apposition of the stomach fundus to the distal part of the esophagus (full thickness plications) and fixation with polypropylene fasteners, 3-0 strength, $\mathrm{H}$-shaped and $7.5 \mathrm{~mm}$ size (34) (Fig. 3). The procedure is carried out with a disposable device, "EsophyX", in its third generation, "EsophyX Z". The new "EsophyX $\mathrm{Z}^{\circledR 1}$ device, approved by the FDA in May
2016, has many advantages over the old

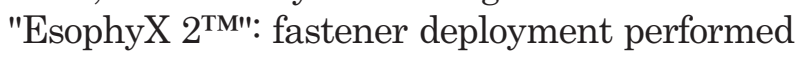
by pulling a trigger similar to surgical staplers, more efficient, dual fastener deployment, safer as the stylets are protected by a sheath (35), shorter operative time, reduced by $50 \%$ (Fig. 4).

Recently, 2 RCTs have shown TIF effectiveness in selected patients with GERD. In the first study, RESPECT, patients with regurgitation and daily PPIs were evaluated: either TIF and placebo, or "sham surgery" and PPI (omeprazole). TIF eliminated regurgitation in $67 \%$ of patients, and PPI only in $45 \%$, esophageal acid exposure(EAE) improved in patients submitted to TIF, but did not normalize (36). TEMPO RCT compared TIF versus PPIs in patients with regurgitation and atypical symptoms: at 6 months, atypical symptoms were absent in $62 \%$ of patients versus $5 \%$. The same study, extended to 3
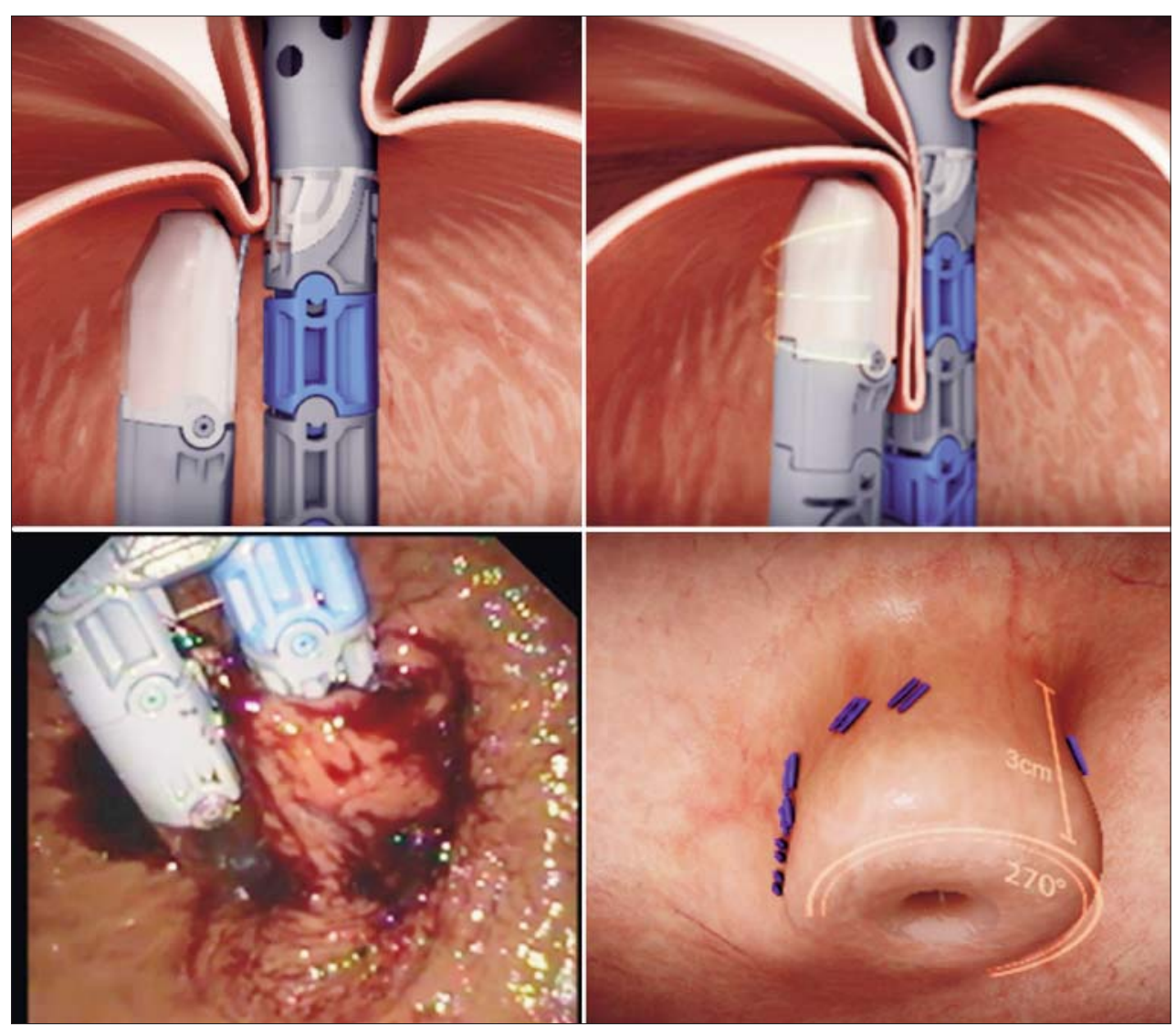

Figure 3. TIF procedure 

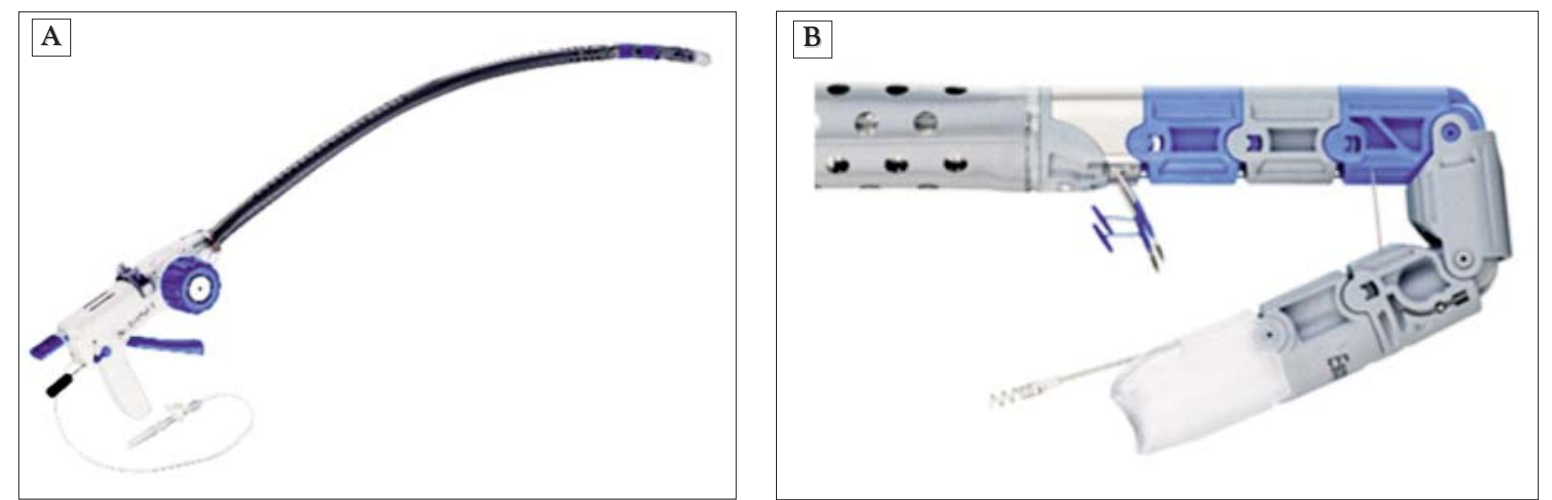

Figure 4. EsophyX device (A) and Distal fastener exiting (B)

years, showed the absence of regurgitation and atypical symptoms in $90 \%$ and $88 \%$ of patients with TIF, $71 \%$ of them no longer using PPIs, and full recovery after esophagitis in $86 \%(37,38)$. 14 patients were evaluated 6 years after TIF: elimination of daily dependence on PPIs in $75-80 \%$ of cases for up to 6 years, $30 \%$ of patients could stop PPI medication at 6 years, AEE (acid esophageal exposure) reduced up to 2 years, while predicting factors for success were pre-procedure Hill's grade I-II, HH absent or $\leq 2 \mathrm{~cm}$, normal esophageal motility, and number of fasteners released (39). A recent meta-analysis of $5 \mathrm{RCTs}, 13$ prospective studies, 963 patients with TIF, reveals an improvement in typical and atypical symptoms, a reduction of intraesophageal acid exposure, a satisfaction rate at six months of $69.15 \%$, the majority of patients discontinuing or reducing PPI use. Complications occurred in $2.4 \%$ of cases (bleeding and perforations), while longtime follow-up showed a reduction in efficacy over time (40). In the case of GERD recurrence after TIF, the procedure may be repeated or LF can be performed, and in the case of recurrence after NLF an EF may be performed with EsophyX or, in those with $\mathrm{HH} \geq 2 \mathrm{~cm}$, through hybrid intervention, initially laparoscopic for HH cure, and then TIF (41-43).

TIF is a safe, effective, and durable alternative in GERD patients who do not respond completely to PPI, without severe reflux and with minimal $\mathrm{HH}$. In conclusion, TIF can be performed with an acceptable safety risk in appropriately selected patients, being strongly recommended by SAGES (44).

Medigus Ultrasonic Surgical Endostapler (MUSE ${ }^{\text {TM) }}$ is an endoscope equipped with an ultrasound transducer and endostapler $(5 \mathrm{x}$ $4.8 \mathrm{~cm}$ titanium clips). The optimal site for stapling, proximal to the $\mathrm{Z}$ line, is detected through ultrasound or video imaging, followed by a partial anterior fundoplication (Fig. 5). 66 patients were evaluated at 6 months after the

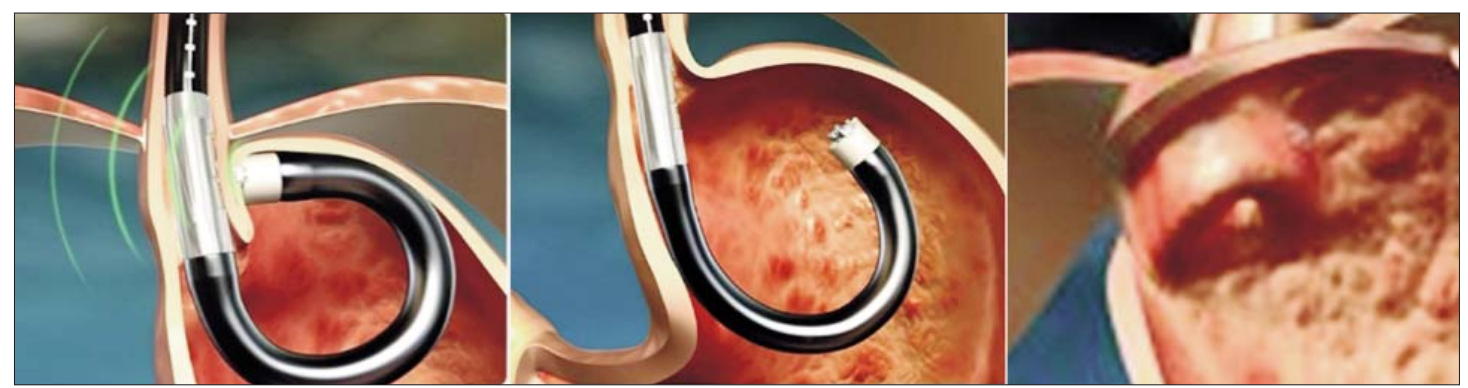

Figure 5. (A) Muse procedure 
procedure: the GERD-HRQL score improved, forty-two patients $(64.6 \%)$ discontinued PPI, EAE decreased with baseline PPI medication (45). In a multicentre study, 66 patients were evaluated at 4 years after the procedure: significant reduction in GERD-HRQL scores, $69.4 \%$ no longer used PPIs at 4 years, reduction of EAE and DeMeester score at 6 months (46). The procedure is effective and safe, but randomized trials and a long period of follow-up are necessary.

Endoscopic full thickness plication with GERDx $^{\text {TM }}$. This device is the evolution of the NDO Plicator (no longer available). Based on plicator technology, the new device is disposable and has an excellent manoeuvrability through microhydraulic technology. The stitches emerging from the stapler present two plates of PTFE at their ends, which reinforce the suture (47) (Fig. 6). The pre-tied sutures are applied on the gastric wall between pledgets (48) (Fig. 7). The results of endoscopic plication with the old device (NDO Plicator) were good, even compared to laparoscopic fundoplication (48). EF with the new GERDx device is currently rated in a single published work. The procedure was applied in 28 patients. The 3 -month mean Gastrointestinal Quality of Life Index scores, DeMeester scores, and general and refluxspecific scores improved, with 3 complications reported. In conclusion, endoscopic plication using the GERDx device may be effective in improving the quality of life and GERD symptoms. Only short term data available with very few patients. More patients and longer term follow up is expected.

The ARMS procedure (anti-reflux mucosec-

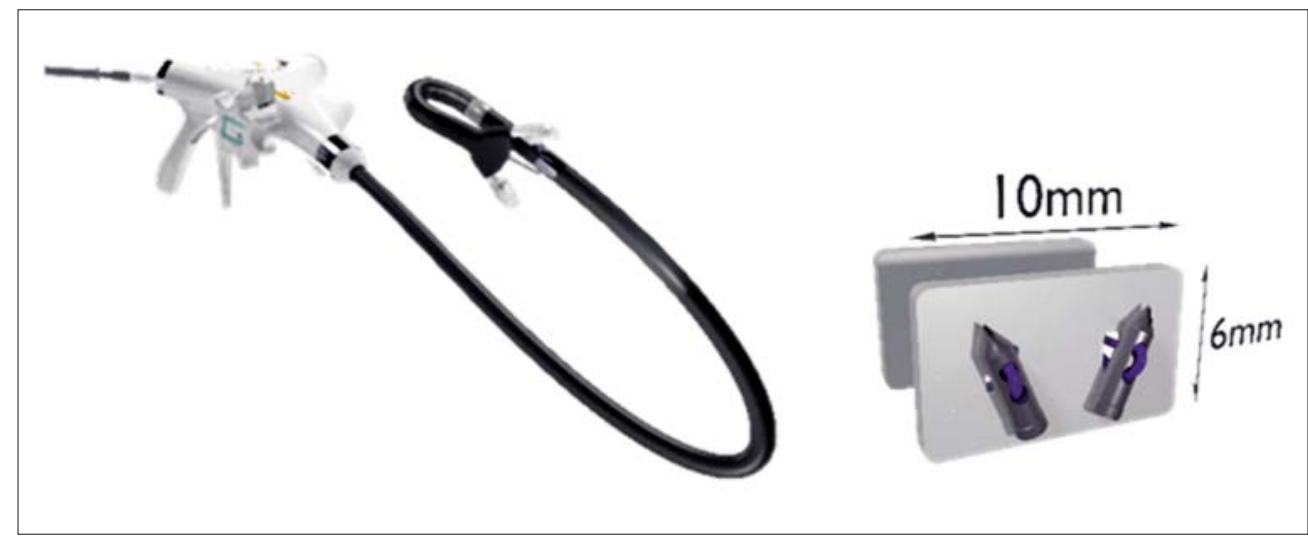

Figure 6. Gerd-X device

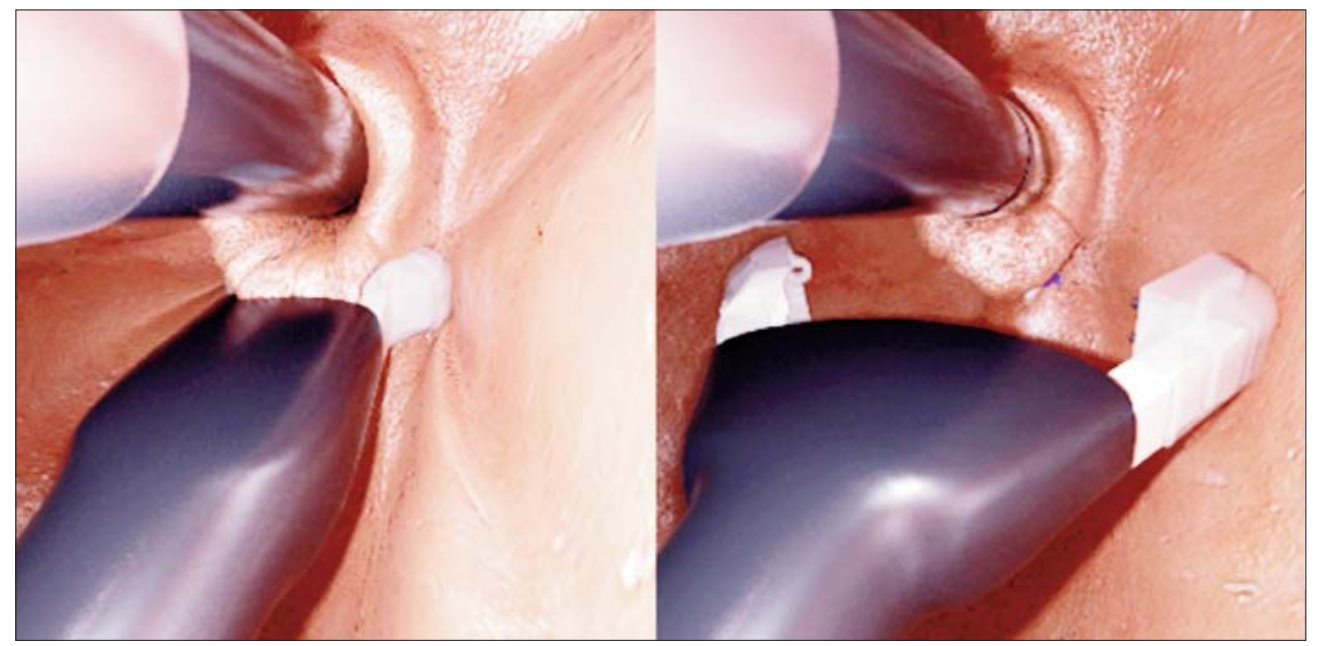

Figure 7. GERD-X procedure 
tomy) is based on the principle that after Esophageal mucosal resection (EMR) or Esophageal Submucosa dissection (ESD) with an electrocautery knife, the mucosal healing results in scar formation, narrowing of the GEJ, remodelling of the mucosal flap valve and reduced reflux. The safety and efficacy of EMR/ESD have been frequently reported and the procedures are now widely applied for $\mathrm{BE}$ with high-grade dysplasia (49). In a pilot study, 10 patients with refractory GERD were submitted to ARMS, the results being that EAE and all scores (DeMeester, heartburn, regurgitation) improved, the best results being reported in patients without sliding hernia (50). In a preliminary, prospective study, ESD was performed on 13 patients with drug-refractory GERD: in 12 cases, symptoms significantly improved, five patients demonstrated improved esophagitis, three were able to discontinue PPI therapy, and three were able to reduce their PPI dosage following surgery (51). Recently, Inoue $\mathrm{H}$ et al. presented the results of ARMS on 67 patients with very good results at one year: improvements in symptomatology and EAE, PPI therapy discontinued in $55 \%$ of patients (52). Prospective studies are required, the number of patients evaluated at the moment being a small one. Postoperative dysphagia is a potential complication.

\section{New (unconventional) Laparoscopic Procedures}

Unconventional laparoscopic procedures are new techniques that perform $\mathrm{HH}$ cure when appropriate, but the fundoplication required for GERD therapy is replaced by other techniques that aim to improve inefficient LES function, which can be performed more easily, and with reduced negative side effects. For the time being, there are two established techniques with proven effectiveness: Magnetic Sphincter Augmentation with the LINX® reflux management system (Torax Medical, Showreview, USA) and Electrical Sphincter Stimulation with Endostim® (Endostim BV, The Hague, The Netherlands).
Magnetic sphincter augmentation uses the $\operatorname{Lin} x^{\circledR}$ device. The device consists of a series of titanium beads with a magnetic core connected with titanium wires to form a ring. This ring is placed around the GEJ, posterior between the esophagus and the vagus nerve. The device helps to augment mecanically the pressure of the LES, preventing reflux. Each magnetic bead, $5.8-\mathrm{mm}$ in diameter, $4.3-\mathrm{mm}$ in width, within its case, is connected by titanium wires that allow adjacent beads to be displaced relative to each other for a maximal fixed distance of $3.6 \mathrm{~mm}$ (53). At higher intraluminal pressures, the magnetic forces are overcome, allowing functions such as swallowing, eructation, or vomiting, while the magnetic attraction helps prevent reflux. In 2012 the FDA approved Linx ${ }^{\circledR}$ for use in the USA. Recently, a new version of $\operatorname{Lin} x{ }^{\circledR}$ is available, which allows MRI imaging up to 1.5 Tesla (53).

In a pilot study, 44 patients with GERD benefited from the $\operatorname{Lin} x{ }^{\circledR}$ device and were evaluated at $1,2,4$, and 5 years after the intervention (53). In all published studies at 1 , 2 and 4 years, a net improvement in quality of life (BRGR-HRQL) of over 50\% was observed, normalized or decreased AEE in over $50 \%$ of cases, while more than $80 \%$ of patients reduced or stopped treatment with PPIs (53). At 5 years, 33 of the 44 initial patients, operated on in 2007 and 2008, were evaluated. The GERD-HRQL score was reduced by over $50 \%$ in $93.9 \%$ of the patients compared to the preoperative score, $90.3 \%$ were satisfied at 5 years, $87.8 \%$ were no longer using PPIs, only $6.1 \%$ still used PPIs in the same dosage as preoperatively, and of the 20 patients who underwent $\mathrm{pH}$-metrics, $80 \%$ showed normalized EAE (14/20), or decrease by over $50 \%$. Moderate postoperative dysphagia present in $43 \%$ of cases was improved over the course of the first 2 years, while 2 patients were submitted to device removal, and one patient was submitted to NLF (54).

In another multicentric study, of the 100 initial patients submitted to treatment using Linx ${ }^{\circledR}, 85$ were available for follow-up 5 years after the procedure. $89.4 \%$ of patients reduced by more than $50 \%$ the average daily dose of 
PPIs, in 14/36 the esophagitis was cured, 5\% presented dysphagia ( $11 \%$ at 1 year). 19 patients required dilatations (in the first year), device removal was necessary in 7 patients, 3 of whom were then submitted to NLF (55). In a pooled analysis of 1,048 patients, overall event rates were $0.1 \%, 1.3 \%$ required readmission, $5.5 \%$ esophageal dilatations, $3.4 \%$ device removal, and $0.1 \%$ presented erosion. The operation is safe (56). It appears that more than 5,500 devices were placed and 190 had to be removed, with $11(0.2 \%)$ cases of erosions (53). Although the MAUDE FDA reported case of explants are 387 cases (57).

In two recent studies, MSA was performed in 52 and 156 patients with $\mathrm{HH}>3 \mathrm{~cm}$, respectively, with good results comparable to those of patients operated on for HH (GERD-HRQL, PPI discontinuation, esophageal dilation for dysphagia) $(58,59)$.

Comparing MSA with NLF in a metaanalysis of 688 patients, at one year postoperatively, differences arose in terms of shorter duration of surgery, possibility of eructation and vomiting, with no significant statistical difference in terms of gas-bloating incidence, discontinuation of PPI, postoperative dysphagia (60). MSA proves itself to be an effective and safe procedure for patients with GERD without severe reflux, but more RCTs are needed for a more accurate assessment, suspicions being related to the presence of a foreign body and the incidence of postoperative dilations that are actually attributable to the operative technique and not to the device. Compared to LF, it is closer to the physiological standard, as it does not significantly alter the anatomy, but addresses more carefully selected patients.

LES Electrical Stimulation with EndoStim ${ }^{\circledR}$ stimulation system, (EndoStim BV, The Hague, The Netherlands) that utilizes electrical stimulation of the LES. The system is similar to neurostimulators with three components: a bipolar stimulation lead with two stitch electrodes implanted by laparoscopy in the LES, a pulse generator implantable in a subcutaneous pocket and an external programmer (61) (Fig. 8). Electrical stimulation increases LES resting pressure and control reflux. The external programmer unit initiates therapy by starting 30-min stimulation cycles 6-12 times a day, with intensity and duration adapted to patient characteristics (25). It has obtained the CE mark in 2012.

Twenty-three patients were included in a 2-year follow-up: there was improvement in their median GERD-HRQL, 71\% of patients demonstrating either normalization or a $\geq$ $50 \%$ decrease in their distal AEE, $76 \%$ of

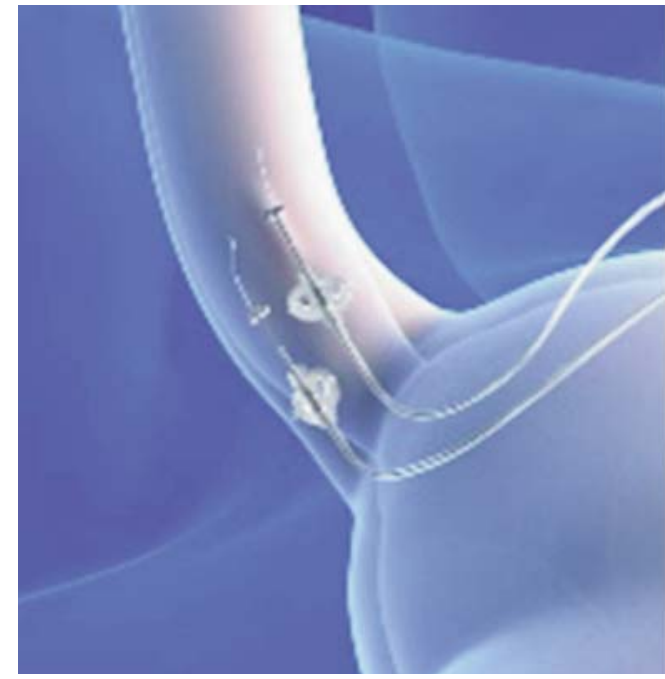

Figure 8 EndoStim device

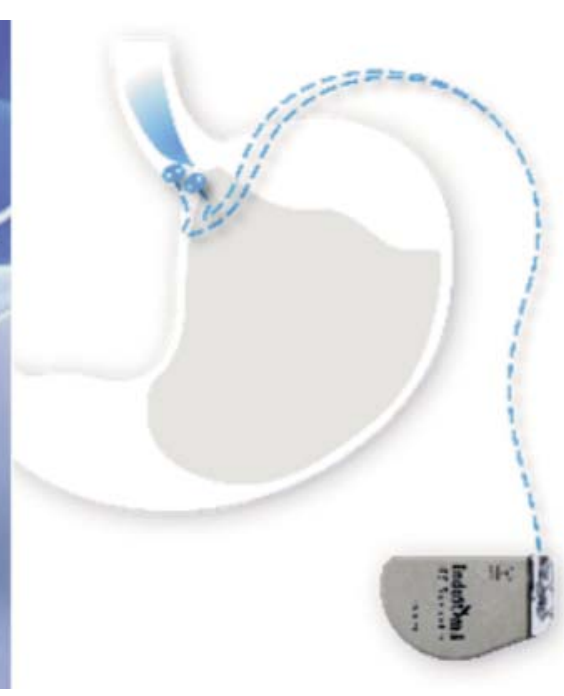


patients discontinued all PPIs, while all patients reported satisfaction with their level of symptom control. There were no serious adverse events or dysphagia (60). Fifteen patients completed their 3-year evaluation: there was a significant improvement in their median GERD-HRQL, 73\% patients had normalized their AEE and $73 \%$ of patients were free of PPIs. There were no adverse events. Due to the minimal anatomical disruption side effects of dysphagia, gasbloating were not encountered (62). In a multicentric trial, 41 patients were evaluated at 6 months. Hiatal repair was performed in 16 patients. GERD-HRQL and AEE improved. One procedure-related, one device-related, and one unrelated severe adverse event were reported: trocar small bowel perforation, asymptomatic lead erosion and a case of paroxysmal atrioventricular nodal reentrant tachycardia (63). Limited experience suggests that electrical stimulation could be efficient in patients with esophageal dismotility (62).

\section{Conclusions}

All these new therapies represent a bridge between PPI patients refractory to medication and with uncontrolled symptoms and LF which is effective long term, but only in experienced hands and centers of reference. More than that, LF very frequently are followed by new post fundoplication syndrome like dysphagia, gas bloat, flatulence and diarrhea, as the disease of GERD is more advanced in the spectrum. However, Nissen LF is the standard in controlling reflux symptoms over long term.

These new endoscopic therapies are indicated for a well selected patient population with early stage disease and refractory to medication (PPI's). These endoscopic approaches augment the LES function and the symptoms (typical or atypical) with complete cessation of PPI or significant reduction (occasionalyy PPI's), resulting in an increase quality of life for these patients. Laparocopic procedures can address $\mathrm{HH}$ larger than $2 \mathrm{~cm}$. They are technically easy less invasive and with reduced adverse events and post fundoplica- tion syndromes in comparing with LF. In case of recurrence, a LF can be performed, so there are no bridges burnt.

We have long term follow up for Esophyx only (at 5 years and 6 years from Randomized Controlled Trials). These are for well selected patient populations with mild symptoms, no complications and no important anatomical disruptions. For Stretta, Muse, EndoStim and Gerd-X the results are promising, but there are only on short term follow up and few number of patients with no randomized clinical trials. The long-term durability has yet to be proven for these last 3 new techniques.Along with permanent improvement of the surgical devices mentioned above, more randomized clinical trials are necessary for Stretta, Muse and EndoStim. They are viable therapeutic options, in evolution, with more and more clarity in GERD therapy and filling the treatment gap.

\section{Conflict of Interests}

Mr. Adrian Lobontiu is Medical Director EndoGastric Solution.

\section{References}

1. El-Serag HB, Sweet S, Winchester CC, Dent J. Update on the epidemiology of gastro-oesophageal reflux disease: a systematic review. Gut. 2014;63(6):871-80

2. Vakil N, van Zanten SV, Kahrilas P, Dent J, Jones R; Global Consensus Group. Global Consensus Group. The Montreal definition and classification of gastroesophageal reflux disease: a global evidencebased consensus. Am J Gastroenterol. 2006;101(8):1900-20; quiz 1943.

3. Torresan F, Mandolesi D, Ioannou A, Nicoletti S, Eusebi LH, Bazzoli F. A new mechanism of gastroesophageal reflux in hiatal hernia documented by high-resolution impedance manometry: a case report. Ann Gastroenterol. 2016;29(4):548-550. Epub 2016 Jun 10.

4. DeMeester TR. Surgical Options for the Treatment of Gastroesophageal Reflux Disease. Gastroenterol Hepatol (N Y). 2017;13(2):128-129.

5. 5 Zhang Y. Epidemiology of esophageal cancer. World J Gastroenterol. 2013;19(34):5598-606

6. Wheeler JB, Reed CE. Epidemiology of esophageal cancer. Surg Clin North Am. 2012;92:1077-1087

7. Katz PO, Gerson LB, Vela MF. Guidelines for the diagnosis and management of gastroesophageal reflux disease.Am J Gastroenterol. 2013;108(3):308-28; quiz 329.

8. Iwakiri K, Kinoshita Y, Habu Y, Oshima T, Manabe N, Fujiwara Y, et al. Evidence-based clinical practice guidelines for gastroesophageal reflux disease 2015. J Gastroenterol. 2016;51(8):75167. doi: 10.1007/s00535-016-1227-8. Epub 2016 Jun 21.

9. Tebala GD. Gastroesophageal reflux disease. Are we acting in the best interest of our patients? Eur Rev Med Pharmacol Sci. 2016; 20(21):4553-4556. 
10. Strand DS, Kim D, Peura DA. 25 Years of Proton Pump Inhibitors: A Comprehensive Review.Gut Liver. 2017;11(1):27-37.

11. Imakiri K, Sakurai Y, Shiino M, Okamoto H, Kudou K, Nishimura A, et al. A randomized, double-blind study to evaluate the acid-inhibitory effect of vonoprazan $(20 \mathrm{mg}$ and $40 \mathrm{mg}$ ) in patients with proton-pump inhibitor-resistant erosive esophagitis. Therap Adv Gastroenterol. 2017;10(6):439-451.

12. Subramanian CR, Triadafilopoulos G. Refractory gastroesophageal reflux disease. Gastroenterol Rep. 2015;3(1):41-53. doi: 10.1093/ gastro/gou061.1177/1756283X17705329

13. Dallemagne B, Perretta S. Twenty years of laparoscopic fundoplication for GERD. World J Surg. 2011;35(7):1428-35.

14. Stefanidis D, Hope WW, Kohn GP, Reardon PR, Richardson WS, Fanelli RD; SAGES Guidelines Committee. Guidelines for surgical treatment of gastroesophageal reflux disease.Surg Endosc. 2010; 24(11):2647-69.

15. Moore M, Afaneh C, Benhuri D, Antonacci C, Abelson J, Zarnegar R. Gastroesophageal reflux disease: A review of surgical decision making. World J Gastrointest Surg. 2016;8(1):77-83.

16. Rickenbacher N, Kötter T, Kochen MM, Scherer M, Blozik E. Fundoplication versus medical management of gastroesophageal reflux disease: systematic review and meta-analysis. Surg Endosc. 2014;28(1):143-55. doi: 10.1007/s00464-013-3140-z. Epub 2013 Sep 10.

17. Robinson B, Dunst CM, Cassera MA, Reavis KM, Sharata A, Swanstrom LL. 20 years later: laparoscopic fundoplication durability. Surg Endosc. 2015;29(9):2520-4. doi: 10.1007/s00464014-4012-x. Epub 2014 Dec 9.

18. Neuvonen P, Sand J, Matikainen M, Rantanen T. Does Nissen fundoplication provide lifelong reflux control? Symptomatic outcome after 31-33 years. World J Surg. 2017;41(8):2046-2052. doi: 10.1007/s00268-017-3924-8.

19. Grant AM, Boachie C, Cotton SC, Faria R, Bojke L, Epstein DM, et al. Clinical and economic evaluation of laparoscopic surgery compared with medical management for gastro-oesophageal reflux disease: 5-year follow-up of multicentre randomised trial (the REFLUX trial). Health Technol Assess. 2013;17(22):1-167. doi: 10.3310/hta17220.

20. Funk LM, Kanji A, Scott Melvin W, Perry KA. Elective antireflux surgery in the US: an analysis of national trends in utilization and inpatient outcomes from 2005 to 2010.Surg Endosc. 2014; 28(5):1712-9. doi: 10.1007/s00464-013-3380-y. Epub 2014 Jan 1.

21. Subramanian CR, Triadafilopoulos G. Refractory gastroesophageal reflux disease.Gastroenterol Rep. 2015;3(1):41-53. doi: 10.1093/ gastro/gou061.1177/1756283X17705329

22. Pandolfino JE, Krishnan K. Do endoscopic antireflux procedures fit in the current treatment paradigm of gastroesophageal reflux disease? Clin Gastroenterol Hepatol. 2014;12(4):544-54. doi: 10.1016/.cgh.2013.06.012

23. Ganz RA. A Review of New Surgical and Endoscopic Therapies for Gastroesophageal Reflux Disease.Gastroenterol Hepatol (N Y). 2016;12(7):424-31.

24. Velanovich V. The development of the GERD-HRQL symptom severity instrument. Dis Esophagus. 2007;20(2):130-4.

25. Azagury DE, Triadafilopoulos G. Minimally Invasive GERD Therapies. In Diagnosis and Treatment of Gastroesophageal Reflux Desease, Vaezi MF(ed.).Springer International Publishing Switzerland, 2016:pag. 117-144.

26. Auyang ED, Carter P, Rauth T, Fanelli RD; SAGES Guidelines Committee. SAGES clinical spotlight review: endoluminal treatments for gastroesophageal reflux disease (GERD).Surg Endosc. 2013:27(8):2658-72. doi: 10.1007/s00464-013-3010-8.

27. Pearl J, Pauli E, Dunkin B, Stefanidis D. SAGES endoluminal treatments for GERD. Surg Endosc. 2017;31(10):3783-3790. doi: 10.1007/s00464-017-5639-1

28. Perry KA, Banerjee A, Melvin WS. Radiofrequency energy delivery to the lower esophageal sphincter reduces esophageal acid exposure and improves GERD symptoms: a systematic review and meta-analysis. Surg Laparosc Endosc Percutan Tech. 2012; 22(4): 283-8

29. Noar M, Squires P, Noar E, Lee M.Long-term maintenance effect of radiofrequency energy delivery for refractory GERD: a decade later. Surg Endosc. 2014;28(8):2323-33. doi: 10.1007/s00464-014-3461-6

30. Lipka S, Kumar A, Richter JE. No evidence for efficacy of radiofrequency ablation for treatment of gastroesophageal reflux disease: a systematic review and meta-analysis. Clin Gastroenterol Hepatol. 2015;13(6):1058-67.e1. doi: 10.1016/j.cgh.2014.10.013. Epub 2014 Oct 18

31. Fass R, Cahn F, Scotti DJ, Gregory DA. Systematic review and meta-analysis of controlled and prospective cohort efficacy studies of endoscopic radiofrequency for treatment of gastroesophageal reflux disease. Surg Endosc. 2017;31(12):4865-4882. doi: 10.1007/s00464-017-5431-2. Epub 2017 Feb 23.

32. Noar M, Squires P, Khan S.Radiofrequency energy delivery to the lower esophageal sphincter improves gastroesophageal reflux patient-reported outcomes in failed laparoscopic Nissen fundoplication cohort. Surg Endosc. 2017;31(7):2854-2862. doi: 10.1007/s00464-016-5296-9

33. Pearl J, Pauli E, Dunkin B, Stefanidis D. SAGES endoluminal treatments for GERD.Surg Endosc. 2017;31(10):3783-3790. doi: 10.1007/s00464-017-5639-1. Epub 2017 Jun 22

34. Nicolau AE, Lobontiu A, Constantinescu G. Endoluminal fundoplication (ELF) with EsophyX2 for gastroesophageal reflux desease (GERD)]. Chirurgia (Bucur). 2009;104(4):381-7. Romanian

35. https://www.medgadget.com/2016/05/esophyx-z-gastroesophageal-valve-reconstruction-device-fda-cleared.html

36. Hunter JG, Kahrilas PJ, Bell RC, Wilson EB, Trad KS, Dolan JP, et al Efficacy of transoral fundoplication vs omeprazole for treatment of regurgitation in a randomized controlled trial. Gastroenterology. 2015;148(2):324-333.e5. doi: 10.1053/j.gastro.2014.10.009. Epub 2014 Oct 13

37. Trad KS, Barnes WE, Simoni G, Shughoury AB, Mavrelis PG, Raza M, et al. Transoral incisionless fundoplication effective in eliminating GERD symptoms in partial responders to proton pump inhibitor therapy at 6 months: the TEMPO Randomized Clinical Trial. Surg Innov. 2015:22(1):26-40. doi: 10.1177/1553350614526788. Epub 2014 Apr 21

38. Trad KS, Fox MA, Simoni G, Shughoury AB, Mavrelis PG, Raza M, et al. Transoral fundoplication offers durable symptom control for chronic GERD: 3-year report from the TEMPO randomized trial with a crossover arm. Surg Endosc. 2017; 31(6):2498-2508. doi: 10.1007/ s00464-016-5252-8

39. Testoni PA, Testoni S, Mazzoleni G, Vailati C, Passaretti S. Longterm efficacy of transoral incisionless fundoplication with Esophyx (Tif 2.0) and factors affecting outcomes in GERD patients followed for up to 6 years: a prospective single-center study. Surg Endosc. 2015;29(9):2770-80. doi: 10.1007/s00464-014-4008-6.

40. Huang X, Chen S, Zhao H, Zeng X, Lian J, Tseng Y, et al. Efficacy of transoral incisionless fundoplication (TIF) for the treatment of GERD: a systematic review with meta-analysis. Surg Endosc. 2017; 31(3):1032-1044. doi: 10.1007/s00464-016-5111-7

41. Bell RC, Hufford RJ, Fearon J, Freeman KD.Revision of failed traditional fundoplication using EsophyX transoral fundoplication. Surg Endosc. 2013;27(3):761-7. doi: 10.1007/s00464-012-25427. Epub 2012 Oct 10.

42. Bell RC, Kurian AA, Freeman KD. Laparoscopic anti-reflux revision surgery after transoral incisionless fundoplication is safe and effective. Surg Endosc. 2015;29(7):1746-52. doi: 10.1007/s00464014-3897-8. Epub 2014 Nov 8

43. Ihde GM, Besancon K, Deljkich E.Short-term safety and symptomatic outcomes of transoral incisionless fundoplication with or without hiatal hernia repair in patients with chronic gastro-esophageal reflux disease(abstr.).Am J Surg. 2011;202(6):740-6; discussion 746-7. doi: 10.1016/j.amjsurg.2011.06. 14.

44. Pearl J, Pauli E, Dunkin B, Stefanidis D. SAGES endoluminal treatments for GERD.Surg Endosc. 2017;31(10):3783-3790. doi: 
10.1007/s00464-017-5639-1. Epub 2017 Jun 22

45. Zacherl J, Roy-Shapira A, Bonavina L, Bapaye A, Kiesslich R, Schoppmann SF, et al. Endoscopic anterior fundoplication with the Medigus Ultrasonic Surgical Endostapler (MUSE ${ }^{\mathrm{TM}}$ ) for gastroesophageal reflux disease: 6-month results from a multi-center prospective trial.Surg Endosc. 2015;29(1):220-9. doi: 10.1007/ s00464-014-3731-3. Epub 2014 Aug 19.

46. Kim HJ, Kwon Cl, Kessler WR, Selzer DJ, McNulty G, Bapaye A, et al. Long-term follow-up results of endoscopic treatment of gastroesophageal reflux disease with the MUSE ${ }^{\mathrm{TM}}$ endoscopic stapling device. Surg Endosc. 2016; 30(8):3402-8. doi: 10.1007/s00464015-4622-y. Epub 2015 Nov 4.

47. Iannetti A. Updates on Management of GERD Disease. J Gastrointest Dig Syst. 2017; 7: 523. doi:10.4172/2161-069X.1000523

48. Weitzendorfer M, Spaun GO, Antoniou SA, Tschoner A, Schredl P, Emmanuel K, et al. Interim Report of a Prospective Trial on the Clinical Efficiency of a New Full-thickness Endoscopic Plication Device for Patients With GERD: Impact of Changed Suture Material (abstr.). Surg Laparosc Endosc Percutan Tech. 2017;27(3):163169. doi: $10.1097 /$ SLE. 0000000000000396 .

49. Nabi Z, Reddy DN. Endoscopic Management of Gastroesophageal Reflux Disease: Revisited. Clin Endosc. 2016;49(5):408-416.

50. Inoue $\mathrm{H}$, Ito $\mathrm{H}$, Ikeda $\mathrm{H}$, Sato $\mathrm{C}$, Sato $\mathrm{H}$, Phalanusitthepha $\mathrm{C}$, et al. Anti-reflux mucosectomy for gastroesophageal reflux disease in the absence of hiatus hernia: a pilot study. Ann Gastroenterol. 2014;27(4):346-351.

51. Ota K, Takeuchi T, Harada S, Edogawa S, Kojima Y, Inoue T, et al. A novel endoscopic submucosal dissection technique for proton pump inhibitor-refractory gastroesophageal reflux disease. Scand J Gastroenterol. 2014;49(12):1409-13.

52. Inoue H, Sumi K, Tatsuta $T$, et al. Clinical Results of Antireflux Mucosectomy (ARMS) for Refractory Gerd (abstr. 998).Gastroint Endosc. May 2017Volume 85, Issue 5, Supplement, Page AB120 DOI: http://dx.doi.org/10.1016/j.gie.2017.03.196

53. Ganz RA. A Modern Magnetic Implant for Gastroesophageal Reflux Disease.Clin Gastroenterol Hepatol. 2017;15(9):1326-1337. doi: 10.1016/j.cgh.2016.12.019. Epub 2016 Dec 24

54. Saino G, Bonavina L, Lipham JC, Dunn D, Ganz RA. Magnetic Sphincter Augmentation for Gastroesophageal Reflux at 5 Years: Final Results of a Pilot Study Show Long-Term Acid Reduction and Symptom Improvement. J Laparoendosc Adv Surg Tech A. 2015;
25(10):787-92. doi: 10.1089/lap.2015.0394. Epub 2015 Oct 5.

55. L Ganz RA, Edmundowicz SA, Taiganides PA, et al. Long-term Outcomes of Patients Receiving a Magnetic Sphincter Augmentation Device for Gastroesophageal Reflux. Clin Gastroenterol Hepatol. 2016; 14(5):671-7. doi: 10.1016/j.cgh.2015.05.028

56. Lipham JC, Taiganides PA, Louie BE, Ganz RA, DeMeester TR. Safety analysis of first 1000 patients treated with magnetic sphincter augmentation for gastroesophageal reflux disease.Dis Esophagus. 2015;28(4):305-11. doi: 10.1111/dote.12199. Epub 2014 Mar 11.

57. https://www.accessdata.fda.gov/scripts/cdrh/cfdocs/cfMAUDE/ textResults.cfm?dls=1\&q=VG9yYXg=\&pf=2018\&pn=10\&sc

58. Buckley FP 3rd, Bell RCW, Freeman K, et al.Favorable results from a prospective evaluation of 200 patients with large hiatal hernias undergoing LINX magnetic sphincter augmentation.Surg Endosc. 2017 Sep 21. doi: 10.1007/s00464-017-5859-4.

59. Rona KA, Reynolds J, Schwameis K, Zehetner J, Samakar K, Oh P, et al. Efficacy of magnetic sphincter augmentation in patients with large hiatal hernias. Surg Endosc. 2017;31(5):2096-2102. doi: 10.1007/s00464-016-5204-3. Epub 2016 Aug 23.

60. Skubleny D, Switzer NJ, Dang J, Gill RS, Shi X, de Gara C, et al. LINX® magnetic esophageal sphincter augmentation versus Nissen fundoplication for gastroesophageal reflux disease: a systematic review and meta-analysis. Surg Endosc. 2017; 31(8): 3078-3084. doi: 10.1007/s00464-016-5370-3. Epub 2016 Dec 15.

61. Rodríguez L, Rodriguez P, Gómez B, Ayala JC, Oxenberg D, PerezCastilla $A$, et al. Two-year results of intermittent electrical stimulation of the lower esophageal sphincter treatment of gastroesophageal reflux disease. Surgery. 2015; 157(3):556-67. doi: 10.1016/j.surg. 2014.10.012. Epub 2014 Nov 6.

62. Rodríguez L, Rodriguez PA, Gómez B, Netto MG, Crowell MD, Soffer E. Electrical stimulation therapy of the lower esophageal sphincter is successful in treating GERD: long-term 3-year results. Surg Endosc. 2016;30(7):2666-72. doi: 10.1007/s00464-0154539-5. Epub 2015 Oct 20.

63. Kappelle WF, Bredenoord AJ, Conchillo JM, Ruurda JP, Bouvy ND, van Berge Henegouwen MI, et al. Electrical stimulation therapy of the lower oesophageal sphincter for refractory gastro-oesophageal reflux disease - interim results of an international multicentre trial. Aliment Pharmacol Ther. 2015;42(5):614-25. doi: 10.1111/ apt.13306. Epub 2015 Jul 8. 